\title{
Once a day theophylline; serum concentrations
}

\author{
V NERMINATHAN AND S A McKENZIE \\ Paediatric Chest Clinic, Oldchurch Hospital, Romford
}

SUMMARY Twenty four hour profiles of serum theophylline concentrations were examined in 15 asthmatic children taking a new theophylline preparation once a day. Peak concentrations occurred at a time when nocturnal wheezing is likely. Fluctuation in concentrations throughout the day was greater than with other currently available preparations, but the importance of this has yet to be determined.

Oral theophylline now has a firm place in the day to day management of childhood asthma. ${ }^{1}$ Dosage at 12 hour intervals with a slow release preparation has been shown to result in better compliance and efficiency compared with dosage every 6 hours with a rapidly absorbed preparation. ${ }^{2}$ Peak serum theophylline concentrations after morning dosage with a slow release preparation occur two to six hours later, ${ }^{34}$ corresponding to the time of maximum improvement in pulmonary function. ${ }^{5}$ One study has shown that peak serum theophylline concentrations occur later, after evening dosage, perhaps due to the difference in the rate of absorption of the drug at night. ${ }^{6}$ Another study in adult volunteers ${ }^{7}$ suggests that serum theophylline concentrations may be higher before the morning than the evening dose because the half life of theophylline is slower during the night. Many asthmatic children have their most troublesome symptoms in the early hours of the morning and so theophylline preparations which result in therapeutic concentrations during this time may well be valuable in the management of nocturnal wheezing. Studies in adults ${ }^{8}$ and children ${ }^{9}$ with slow release preparations of aminophylline have suggested that this is the case.

Measurements of pulmonary function in asthmatics with acute asthma treated with intravenous aminophylline have shown that improvement is significant when the serum theophylline concentrations reach $5 \mu \mathrm{g} / \mathrm{ml}(28 \mu \mathrm{mol} / \mathrm{l})$ and correlates with the logarithm of the serum theophylline concentrations between 5 and $20 \mu \mathrm{g} / \mathrm{ml} \mathrm{(28}$ and 110 $\mu \mathrm{mol} / \mathrm{l}) .{ }^{10}{ }^{11}$ Because concentrations greater than 20 $\mu \mathrm{g} / \mathrm{ml}(110 \mu \mathrm{mol} / \mathrm{l})$ are associated with increased frequency of side effects this value has been widely accepted as the upper limit of the therapeutic range.

One of the earliest studies in children with chronic asthma, which tried to relate improvement in control to serum theophylline concentrations after oral aminophylline, suggested that those children with concentrations greater than $10 \mu \mathrm{g} / \mathrm{ml}$ (55 $\mu \mathrm{mol} / \mathrm{l})$ had fewer symptoms. ${ }^{12} \mathrm{~A}$ more recent study in 'stable' adult asthmatics, ${ }^{13}$ which questions the value of maximising serum theophylline concentrations, showed improvement in pulmonary function until concentrations reached approximately $13 \mu \mathrm{g} / \mathrm{ml}$ ( $72 \mu \mathrm{mol} / \mathrm{l})$, but no further significant improvement at concentrations approaching $20 \mu \mathrm{g} / \mathrm{ml} \quad(110$ $\mu \mathrm{mol} / \mathrm{l})$. There is good evidence that control is satisfactory in many children with concentrations lower than $10 \mu \mathrm{g} / \mathrm{ml}(55 \mu \mathrm{mol} / \mathrm{l}) .{ }^{14}$ Thus a range of serum theophylline concentrations of 5 to $20 \mu \mathrm{g} / \mathrm{ml}$ (28 to $110 \mu \mathrm{mol} / \mathrm{l}$ ) probably reflects the therapeutic range. To what extent fluctuation in serum theophylline concentrations affects day to day control in chronic asthmatics has yet to be defined, and it is possible that although different preparations produce different pharmacokinetic data, they may not result in differences in overall clinical efficacy. ${ }^{4}$

A new slow release theophylline preparation (Uniphyllin, Napp Laboratories, UK) has been designed to release theophylline even more slowly than currently available preparations. Preliminary studies in adults suggest that concentrations of 5 to $20 \mu \mathrm{g} / \mathrm{ml}(28$ to $110 \mu \mathrm{mol} / \mathrm{l})$ can be achieved for most of a 24 hour period after a single dose, and that peak concentrations occur at about 6 hours after dosage. ${ }^{15}$ The purpose of this study was to determine for what proportion of a 24 hour period serum theophylline concentrations could be maintained within the therapeutic range in a group of asthmatic children each given a single dose of Uniphyllin in the evening, and at what time peak concentrations occurred. 


\section{Patients and methods}

Fifteen asthmatic children between the ages of 6 and 13 years (mean 10.1 years) were studied. All had been referred recently to the children's chest clinic because of poorly controlled symptoms and all were considered to require daily maintenance treatment. The purpose and nature of the study were explained to both the children and their parents and consent to take part was obtained. Approval for the study was given by the hospital ethical review committee.

Uniphyllin is marketed in $400 \mathrm{mg}$ and $200 \mathrm{mg}$ tablets. Each is scored and can be broken once. The daily dose for each child was as near as possible 15 to $20 \mathrm{mg} / \mathrm{kg}$ and was given at $8 \mathrm{pm}$. All subjects had received this dose for at least three days before the study. Each child was admitted to hospital in the early evening of the study period and an indwelling cannula, kept patent with heparinised saline, was inserted into a forearm vein. Blood for serum theophylline measurement was collected just before the dose for that day and thereafter at 2 hour intervals for the next 24 hours.

The serum theophylline concentrations were measured using an EMIT (Syva) assay.

\section{Results}

The serum theophylline concentrations for each child are presented in the Table. The mean and standard deviation of the concentrations for the group are shown in Fig. 1. Three children had peak concentrations greater than $20 \mu \mathrm{g} / \mathrm{ml}(110 \mu \mathrm{mol} / \mathrm{l})$; 23,23 , and $27 \mu \mathrm{g} / \mathrm{ml}(127,127$, and $149 \mu \mathrm{mol} / \mathrm{l})$. The times that peak concentrations were obtained are also shown in the Table: in 10 of the 15 children

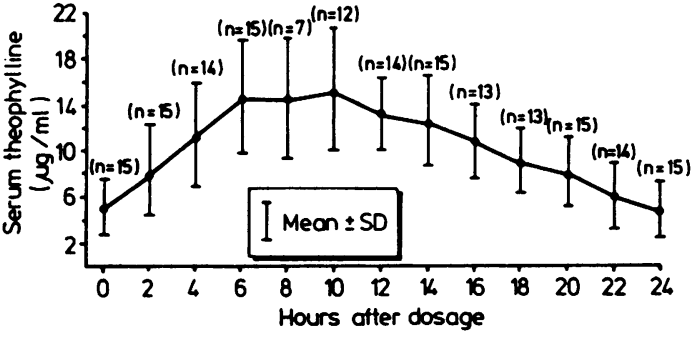

Fig. 1 Mean serum theophylline concentrations $(\mu \mathrm{g} / \mathrm{ml})$ over 24 hours.

Conversion-traditional units to SI: Serum theophylline $1 \mu \mathrm{g} / \mathrm{ml} \approx 5.5 \mu \mathrm{mol} / \mathrm{l}$.

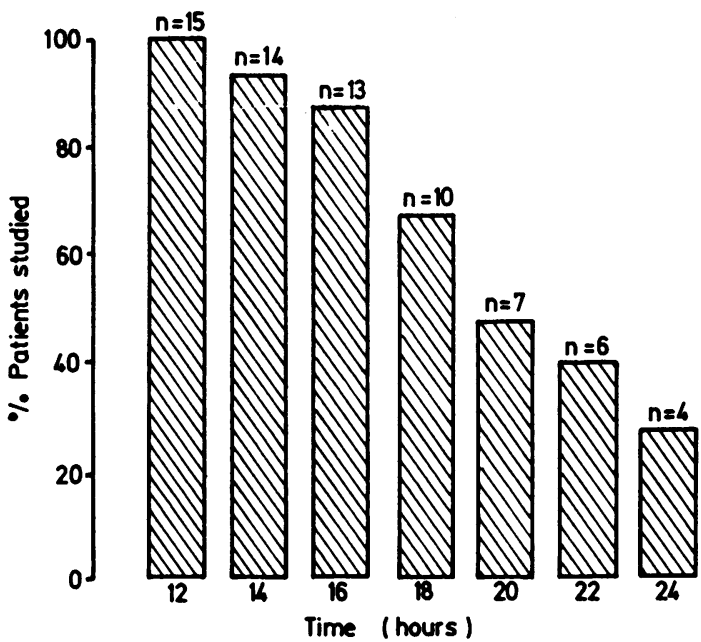

Fig. 2 Minimum length of time over which concentrations greater than $5 \mu \mathrm{g} / \mathrm{ml}$ were sustained throughout a 24 hour period.

Conversion-traditional units to SI: Serum theophylline $1 \mu \mathrm{g} / \mathrm{ml} \approx 5 \cdot 5 \mu \mathrm{mol} / \mathrm{l}$.

Table Serum theophylline concentrations ( $\mu \mathrm{g} / \mathrm{ml}$ ) over a 24 hour period

\begin{tabular}{|c|c|c|c|c|c|c|c|c|c|c|c|c|c|c|c|c|c|}
\hline $\begin{array}{l}\text { Patient } \\
\text { No }\end{array}$ & $\begin{array}{l}\text { Age } \\
\text { (years) }\end{array}$ & $\begin{array}{l}\text { Dosage } \\
(\mathrm{mg} / \mathrm{kg})\end{array}$ & \multicolumn{13}{|c|}{ Hours after dosage } & $\begin{array}{l}\text { Time of } \\
\text { peak concen- } \\
\text { tration (hours } \\
\text { after dosage) }\end{array}$ & $\begin{array}{l}\text { Minimum } \\
\text { time (hours) } \\
\text { concentration } \\
\text { remained } \\
>5 \mu \mathrm{g} / \mathrm{ml}\end{array}$ \\
\hline 1 & 11 & $20 \cdot 0$ & $10 \cdot 4$ & $14 \cdot 9$ & $16 \cdot 0$ & $14 \cdot 2$ & $13 \cdot 7$ & $12 \cdot 7$ & $11 \cdot 3$ & $10 \cdot 7$ & $11 \cdot 3$ & - & $9 \cdot 1$ & - & $8 \cdot 2$ & 4 & 24 \\
\hline 2 & 8 & $21 \cdot 0$ & 3.4 & 4.9 & $4 \cdot 5$ & $4 \cdot 8$ & 6.4 & $7 \cdot 8$ & $11 \cdot 3$ & $11 \cdot 3$ & 11.3 & 9.8 & $7 \cdot 6$ & $4 \cdot 7$ & $3 \cdot 3$ & $12-16$ & 12 \\
\hline 3 & 10 & $17 \cdot 4$ & $2 \cdot 9$ & $6 \cdot 6$ & $12 \cdot 7$ & $15 \cdot 9$ & $17 \cdot 3$ & $14 \cdot 6$ & $10 \cdot 4$ & $8 \cdot 7$ & $7 \cdot 2$ & 5.9 & $4 \cdot 4$ & $3 \cdot 2$ & $2 \cdot 5$ & 8 & 16 \\
\hline 5 & 13 & $20 \cdot 7$ & $4 \cdot 5$ & $7 \cdot 3$ & - & $15 \cdot 3$ & 18.9 & $16 \cdot 3$ & $13 \cdot 8$ & $12 \cdot 5$ & 14.9 & - & $13 \cdot 1$ & $12 \cdot 0$ & $2 \cdot 4$ & 8 & 20 \\
\hline 6 & 10 & $16 \cdot 4$ & $4 \cdot 4$ & $3 \cdot 4$ & $10 \cdot 0$ & $17 \cdot 4$ & $16 \cdot 9$ & - & $12 \cdot 1$ & $11 \cdot 8$ & $10 \cdot 2$ & 9.4 & 9.4 & $5 \cdot 8$ & $4 \cdot 4$ & 6 & 18 \\
\hline 7 & 13 & $15 \cdot 7$ & $6 \cdot 7$ & $7 \cdot 4$ & $7 \cdot 3$ & 8.0 & $8 \cdot 5$ & - & $12 \cdot 9$ & $13 \cdot 6$ & 14.4 & $12 \cdot 5$ & $10 \cdot 9$ & 9.4 & $9 \cdot 4$ & 16 & 24 \\
\hline 8 & 10 & $18 \cdot 1$ & $4 \cdot 4$ & $10 \cdot 2$ & $11 \cdot 6$ & $16 \cdot 2$ & - & - & - & $23 \cdot 0$ & - & $15 \cdot 1$ & $12 \cdot 6$ & 8.9 & $6 \cdot 7$ & $8-14$ & 22 \\
\hline 9 & 13 & $18 \cdot 1$ & $3 \cdot 8$ & $18 \cdot 2$ & $21 \cdot 0$ & $23 \cdot 0$ & - & $17 \cdot 7$ & $14 \cdot 8$ & $14 \cdot 1$ & - & $7 \cdot 1$ & 7.9 & 3.9 & $4 \cdot 1$ & $6-8$ & 18 \\
\hline 10 & 6 & $18 \cdot 4$ & $6 \cdot 8$ & 11.9 & $17 \cdot 2$ & 16.9 & - & $13 \cdot 3$ & $10 \cdot 8$ & $8 \cdot 0$ & 6.6 & $4 \cdot 2$ & $3 \cdot 3$ & $2 \cdot 3$ & 1.8 & 4 & 16 \\
\hline 11 & 8 & $19 \cdot 1$ & $2 \cdot 0$ & $8 \cdot 3$ & $12 \cdot 7$ & $12 \cdot 8$ & - & $11 \cdot 5$ & 9.9 & $8 \cdot 1$ & $7 \cdot 1$ & $6 \cdot 2$ & $4 \cdot 6$ & $3 \cdot 1$ & $2 \cdot 2$ & $6-8$ & 16 \\
\hline 12 & 6 & $18 \cdot 3$ & 4.0 & $5 \cdot 6$ & $7 \cdot 6$ & $9 \cdot 8$ & - & $9 \cdot 6$ & 9.7 & $8 \cdot 8$ & 8.0 & $9 \cdot 3$ & 8.0 & $6 \cdot 3$ & $7 \cdot 7$ & $6-8$ & 22 \\
\hline 13 & 11 & $15 \cdot 0$ & $8 \cdot 1$ & $6 \cdot 1$ & $10 \cdot 7$ & $18 \cdot 6$ & - & $19 \cdot 1$ & $15 \cdot 6$ & $14 \cdot 5$ & $12 \cdot 5$ & 10.8 & 8.9 & $7 \cdot 5$ & $5 \cdot 7$ & $8-10$ & 24 \\
\hline
\end{tabular}

Conversion-traditional units to $S I$ : serum theophylline $1 \mu \mathrm{g} / \mathrm{ml} \approx 5.5 \mu \mathrm{mol} / \mathrm{l}$. 
studied these peaks occurred between 6 and 10 hours after dosage.

All children achieved concentrations greater than $5 \mu \mathrm{g} / \mathrm{ml}(28 \mu \mathrm{mol} / \mathrm{l})$ for at least 12 hours (Fig. 2) and 10 of 15 for at least 18 hours. The mean difference between peak and trough concentrations was 13 $\mu \mathrm{g} / \mathrm{ml}(72 \mu \mathrm{mol} / \mathrm{l}$ ); range 5.8 to $20.3 \mu \mathrm{g} / \mathrm{ml}$ (32 to 112 $\mu \mathrm{mol} / \mathrm{l})$.

\section{Discussion}

This study has shown that serum theophylline concentrations after a single dose of 15 to $21 \mathrm{mg} / \mathrm{kg}$ of a new slow release theophylline preparation could be sustained above $5 \mu \mathrm{g} / \mathrm{ml}(28 \mu \mathrm{mol} / \mathrm{l})$ for at least 18 hours in 10 of 15 asthmatic children. Three children had peak concentrations greater than $20 \mu \mathrm{g} / \mathrm{ml}(110$ $\mu \mathrm{mol} / \mathrm{l})$; reduction of their dosage to reduce these peak concentrations would probably have resulted in their trough concentrations becoming extremely low. On the other hand, adjustment of the dosage in three other children (patients 2, 11, and 12) might well have brought their trough concentrations above $5 \mu \mathrm{g} / \mathrm{ml}(28 \mu \mathrm{mol} / \mathrm{l})$ without resulting in peak concentrations exceeding $20 \mu \mathrm{g} / \mathrm{ml}(110 \mu \mathrm{mol} / \mathrm{l})$. The mean difference between peak and trough concentrations over 24 hours was $13 \mu \mathrm{g} / \mathrm{ml}(72 \mu \mathrm{mol} / \mathrm{l})$. Differences over 12 hour periods using other slow release preparations have been reported in three other studies as $6.2 \mu \mathrm{g} / \mathrm{ml}(34 \mu \mathrm{mol} / \mathrm{l})$ and $7.9 \mu \mathrm{g} / \mathrm{ml}$ $(43 \mu \mathrm{mol} / \mathrm{l}),{ }^{3} 5 \cdot 2 \mu \mathrm{g} / \mathrm{ml}(29 \mu \mathrm{mol} / \mathrm{l})$ and $8.7 \mu \mathrm{g} / \mathrm{ml}(48$ $\mu \mathrm{mol} / \mathrm{l}),{ }^{4}$ and $4.6 \mu \mathrm{g} / \mathrm{ml}(25 \mu \mathrm{mol} / \mathrm{l}) .{ }^{5}$ When differences are examined over a 24 hour period, however, using a twice daily dosage, they seem to be larger, $6.5 \mu \mathrm{g} / \mathrm{ml}(36 \mu \mathrm{mol} / \mathrm{l})$ compared with $4.5 \mu \mathrm{g} / \mathrm{ml}(25$ $\mu \mathrm{mol} / \mathrm{l})$ over 12 hours $^{16}$ and $9.0 \mu \mathrm{g} / \mathrm{ml}(50 \mu \mathrm{mol} / \mathrm{l})$ compared with $7.4 \mu \mathrm{g} / \mathrm{ml}(41 \mu \mathrm{mol} / \mathrm{l}) .{ }^{6}$ Similarly, the percentage change of peak in relation to trough concentrations is larger for this preparation.

These figures, however, should be interpreted with caution. Because of the wide interpatient variation in absorption and clearance of theophylline, the information from mean data obscures what is significant for the individual. For example the serum theophylline concentrations in patient 1 are reasonably stable throughout the day, whereas those in patients 9 and 15 show large differences in peak and trough concentrations. In addition, the absorption of slow release theophylline preparations is known to vary within patients from day to day ${ }^{17} 18$ and during the day, ${ }^{6}$ and with food in the stomach. ${ }^{19}$ Information regarding variability of absorption with and without food in the stomach and with changes in gastric emptying times, for example related to exercise, is not available for children. Clearance rates of theophylline also show intrapatient variability. ${ }^{20}$ Thus the data presented here (as with data for other theophylline preparations) for each individual as well as for the group as a whole should be regarded only as a guideline for treatment schedules.

As long as the serum theophylline concentrations do not cause toxic symptoms or appreciably exceed $20 \mu \mathrm{g} / \mathrm{ml}(110 \mu \mathrm{mol} / \mathrm{l})$, what is important is whether the concentrations produced, whatever they are, control the symptoms and provide protection against bronchoconstrictor triggers. Whether the degree of fluctuation throughout the 24 hour period with the preparation used in this study results in considerably poorer day to day control than other slow release preparations given every 12 hours needs now to be examined. As with all theophylline preparations, serum theophylline concentrations should be measured throughout the day to know whether potentially toxic concentrations are being reached. Even when concentrations are judged to be within the therapeutic range, however, viral infections such as influenza may delay clearance and toxic symptoms may result. ${ }^{21}$

Peak concentrations occurred in most children 6 to 10 hours after the dosage, at a time when night time wheezing is most likely. It would seem, therefore, that this slow release theophylline preparation, given once a day in the evening, may be useful in the management of nocturnal asthma and may well be a useful adjunct to treatment with disodium cromoglycate or inhaled corticosteroids. The lower concentrations throughout the day may not be sufficient to control symptoms in some children if the drug is given alone, but in other children may afford adequate protection. This can only be determined by evaluating each child treated.

We thank Sally and George Padmore who measured the serum theophylline concentrations and without whose cooperation and assistance this study would not have been possible.

\section{References}

1 McKenzie SA. Sympathomimetics and theophylline derivatives in the management of childhood asthma. Topics in paediatrics 3 . Royal College of Physicians. London: Pitman;1982:62-71.

2 Tabachnik E, Scott P, Correia J, et al. Sustained-release theophylline: a significant advance in the treatment of childhood asthma. J Pediatr 1982;100:489-92.

${ }^{3}$ McKenzie SA, Baillie E. Serum theophylline levels in asthmatic children after oral administration of two slow-release theophylline preparations. Arch Dis Child 1978;53:943-6.

${ }^{4}$ Menendez R, Kelly HW, Howick J, McWilliams BC. Sustainedrelease theophylline: pharmacokinetic and therapeutic comparison of two preparations. Am J Dis Child 1983;137:469-73.

5 Bell T, Bigley J. Sustained-release theophylline therapy for chronic childhood asthma. Pediatrics 1978;62:352-8.

${ }^{6}$ Scott PH, Tabachnik E, Macleod S, Correia J, Newth C, 
Levison H. Sustained-release theophylline for childhood asthma: evidence for circadian variation of theophylline pharmacokinetics. J Pediatr 1981:99:476-9.

7 Jonkman JHG, van der Boon WJV. Nocturnal theophylline plasma concentrations. Lancet 1983;i:1278-9.

${ }^{8}$ Barnes P, Greening AP, Neville L. Timmers J, Poole GW. Single-dose slow-release aminophylline at night prevents nocturnal asthma. Lancet 1982;i:299-301.

9 Evans PW, Craven A, Evans N. Nocturnal wheezing in children: management with controlled-release aminophylline. Br Med J 1981;283:18.

${ }^{10}$ Mitenko PA, Ogilvic RI. Rational intravenous doses of theophylline. $N$ Engl J Med 1973;289:600-3.

"Levy G, Koysooko R. Pharmacokinetic analysis of the effect of theophylline on pulmonary function in asthmatic children. J Pediatr 1975;86:789-93.

12 Weinberger MM, Bronsky EA. Evaluation of oral bronchodilator therapy in asthmatic children. J Pediatr 1974;84:421-7.

13 Klein JJ, Lefkowitz MS. Spector SL, Cherniak RM. Relationship between serum theophylline levels and pulmonary function before and after inhaled beta-agonist in 'stable' asthmatics. Am Rev Respir Dis 1983;127:413-6.

${ }^{14}$ Rachelefsky GS. Katz RM. Siegel SC. A sustained release theophylline preparation: efficacy in childhood asthma with low serum theophylline. Ann Allergy 1978;40:252-7.
15 Nolte D, Newumann M. Uniphyllin Unicontin tablets: pharmacokinetic investigations using a new retard preparation. Br J Clin Pract [Symph Suppl] 1983;23:89-94.

16 Kelly HW, Murphy S. Efficacy of a 12-hour sustained-release preparation in maintaining therapeutic serum theophylline levels in asthmatic children. Pediatrics 1980;66:97-102.

17 Watson PD, Strank RC, Taussig LM. Intrapatient variability in theophylline kinetics. J Pediatr 1977;91:321-3.

${ }^{18}$ Dederich RA, Szeffer SJ, Green ER. Intrasubject variation in sustained-release theophylline absorption. $J$ Allergy Clin Immunol 1981;67:465-71.

19 Pederson S. Delay in the absorption rate of theophylline from a sustained release theophylline preparation caused by food. $\mathrm{Br} \mathrm{J}$ Clin Pharmacol 1981;12:904-5.

${ }^{20}$ Leung P, Kalisker A, Bell TD. Variation in theophylline clearance rate with time in chronic childhood asthma. J Allergy Clin Immunol 1977;59:440-4.

${ }^{21}$ Walker SB, Middelkamp JN. Theophylline toxicity and viral infections. Pediatrics 1982;70:508-9.

Correspondence to Dr S A McKenzie, Rush Green Hospital, Romford, Essex RM7 0YA.

Received 21 February 1984 